\title{
STEVAN TODOROVIĆ, LIFE AND WORK OF A PERFORMER, ARTIST, EDUCATOR AND FOUNDER OF ORGANIZED SPORT IN SERBIA
}

\author{
Vladan Vukašinović \\ The University of Belgrade, Faculty of Sport and Physical Education, Serbia
}

\begin{abstract}
In 2017, 160 years were marked since the beginning of the organized physical exercise (1857) and 126 years since the emergence of Sokol movement in Serbia (1891). The great contribution of Academics Steva Todorovic, Dr. Vladan Djordjevic and Dr. Vojislav Rasic to the beginning and development of physical culture in the Principality and the Kingdom of Serbia, was evoked. 160 years since the arrival of Academic Stevan Todorovic in the capital of Belgrade, in which he started his cultural and enlightenment work in 1857, was also denoted. At the „School of Painting” which he opened, "Group for Gymnastics and Fighting" was also founded, as the first organized association for physical exercise. This Group preceded the idea of acceptance of "Sokolstvo", the development of modern sport and the affirmation of physical culture in Serbia. The aim of this paper is to highlight the contribution of academic Steva Todorovic to the overall cultural and educational progress of Serbia, including physical culture. The historical method was compiled of authentic documents from 1899, 1908, 1912, 1927, 1938 which were not available and known to the wider and professional public, gymnastic and Sokol membership.
\end{abstract}

Key Words: STEVAN TODOROVIC / PHYSICAL CULTURE / EDUCATION / CULTURE / ART / SERBIA

\section{INTRODUCTION}

Among the prominent promoters of physical exercising in Serbia, who are even today, after more than a century, considered charismatic visionaries of gymnastic and Sokol exercising, we include Vladan Đorđević, Vojislav Rašić, Laza Popović, Miroslav Vojinović... However, among these famous beginners of the physical exercising movement, we must add one more great man of Serbian gymnastics and Sokol movement, as their true founder - Stevan "Steva" Todorović (Vukašinović, 2016). He was the first to leave and impress an undeniable and strong mark, in his own manner, on the emergence of organised physical exercising and founding and development of civilian gymnastic and cultural societies in the framework of socio-cultural changes in Serbia from the middle of the 19th and until the beginning of the 20th century.

\section{STEVAN TODOROVIĆ - BIOGRAPHY OF A YOUNGER PERFORMER}

StevanTodorović (13/04/1832, Novi Sad $22 / 05 / 1925$, Belgrade), was by origin from Herzegovina. His father Jovan, from the town of Trebinje, a Herzegovinian rebel, participated in the First Serbian Uprising for seven years, since he was 19, until he suffered a minor wound. When the Ottomans descended in great force upon the rebels, he survived by fleeing across the Sava river to the Austrian bank, to Bežanija, near the town of Zemun. By chance there he met his parents and from there they moved to Novi Sad, where they traded in Turkish tobacco. Stevan's mother Jelena, from Bela Palanka in the foothills of Mt. Avala, related to the Uprising leader Vasa Čarapić through the female line, also fled from Serbia with her parents to Novi Sad where they successfully continued their trading business (Simić, 1951).

118 Correspondence to: Vladan Vukašinović, Faculty of Sport and Physical Education, Blagoja Parovića 156, 11300 Belgrade, e-mail: vladan.vukasinovic@fsfv.bg.ac.rs 


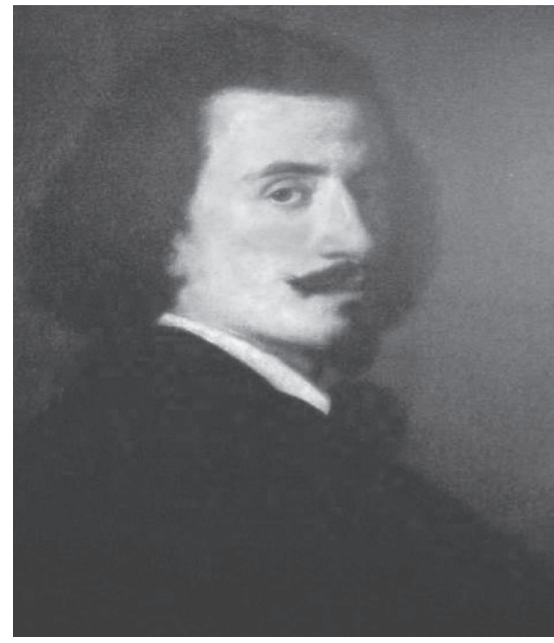

Photo 1. Stevan Todorović

Stevan was born in Novi Sad, in a family with seven children - four sons and three daughters. The tobacco trade brought to the family a significant income until 1937, when their shop and house burnt in a great fire. Stevan enrolled at a Novi Sad elementary school, but when he was seven, he moved with his parents to Szeged, where his parents bought a warm and a cold public bath by the Tisa river. Between 1839 and 1846 he finished elementary school in Szeged and five years of high school. At the Serbian Elementary School, supported by the Serbian Orthodox Church, Steva learned to write according to the orthography of Vuk Karadžić from the deacon Dimitrije Popović. The educational influence of this teacher, who was famous for being a cousin of Đura Daničić and Karadžićs supporter in the reform of the Serbian language and orthography, was enormous during the school years of the gifted and erudite Todorovic (Simić, 1951). The famous gymnastics and martial arts teacher at the Szeged High School, Đorđe Marković Koder, also had a huge influence on Stevan's life (Todorović, 1968). The young high school student was impressed by gymnastics and fencing and this would be important for the building of Todorovićs personality, which the future would confirm.

In the middle of 1846 his father took him to Vienna for further education and there he finished the sixth and seventh year of high school. After the graduation he enrolled at the Vienna Lyceum, where he studied philosophy. When the 1848 Revolution erupted, he was recruited into the student regiment, which allowed him to support himself, since his contact with his family was interrupted by the war, and because his father had died some time earlier that same year, without him knowing.

After the defeat of the revolution in 1849 Steva returned from Vienna and went to Belgrade to his uncle who took care of his further education. In his brewery he learned how to produce beer, but every free moment he used "to draw and paint with watercolours, every wall was covered with his works". The uncle, recognising Steva's talent and his, since childhood, only desire - to become a painter, took him to Vienna in 1850 and enrolled him at the second semester of the Academy of Fine Arts.

The life circumstances in his youth were not inclined towards Todorović, but he made his path on his own during his school years, without a scholarship. Six weeks after the enrolment at the Academy his uncle died and Steva lost a monthly income of 150 forints. He returned to Belgrade to inherit his uncle's property, only to find his uncle's house robbed. Soonafter, both the house and the brewery were taken from him by a banker and a pasha, and the entire scheme was devised by Steva's lawyer. After his return to Vienna, Steva enrolled at Professor Waldmüller's private school. The assistance from his mother was not enough to pay for his education and he was forced to support himself until the end of 1852 by giving private drawing and singing lessons. His inseparable friend KornelijeStanković with whom he shared a flat, taught him to sing, because he was a wonderful baritone, and while he studied in Vienna some suggested that he should study opera singing (Simić, 1951).

This was a difficult period for Steva. Without any income he returned to his mother in Szeged, and then went to Vienna, after which he enrolled at the Munich Academy of Fine Arts (at the end of 1853), but after nine months, because of lack of money, he returned to study in Vienna (1854) with the famous professor Carl Rahl. In the meantime, he spenthis money once more and returned to Szeged to visit his mother and earn more for his studies. He painted portraits in several places in Vojvodina and went to Novi Sad (in the fall of 1855) where he spent ten months. With the teachers of the Serbian High School ĐorđeNatošević, Jovan Gavrilović and Jovan Đorđević he practiced gymnastics and fencing in the High School gymnastics department and there he discussed the importance of exercising. In the spring of 1856 he joined KornelijeStanković as a "sonorous" baritone at his concerts in larger towns and he got a third of their earnings to continue his studies. Steva became a fa- 
mous baritone who "always left a great impression at concerts", and in the fall of 1856 he had a very successful concert in Belgrade, "when all the cultured Belgrade met him for the first time". He went to Vienna once again and stayed in Carl Rahl's school until April 1857, where he was remembered as the most successful among the first Serbian painters (Todorović, 1899; Jeftimijades, 1938; Simić, 1951).

\section{STEVAN TODOROVIĆ, PERFORMER AND GYMNASTICS, MARTIAL ARTS, SINGING TEACHER}

During his stay in Munich Steva practiced gymnastics and fencing. That was a good opportunity for him to get directly introduced to the system of German tournament gymnastics, as well as to the organisation and methodology of private institutes for exercising. It was probably there that he got the idea to establish a similar association upon his return to Serbia. Destined for wider vocations, Todorović had other interests also. While studying in Vienna, in the circles of the progressive Serbian youth he talked about "the culture which our people are in need of", the educational importance of art, physical exercising, music, singing, and theatre" asnational tasks of the young Serbian intelligentsia "which will make sacrifices for the sake of future generations" (Simić, 1951), so as to catch up with the advanced European nations.

Next year Steva permanently settled in Belgrade (May 1857), and since he was tireless and entrepreneurial he immediately opened the Painting School in Kosančićev venac St., in the house of the iconographer Milija Marković Raspop. In his private "institute" he taught the Lyceum students to draw, paint, sing, he told and interpreted the Iliad for them, reciting Shakespeare's tragedies, and as a great aficionado of physical exercising, he taught them gymnastics and fencing, all for free. On his enthusiasm Steva wrote the following in his Autobiography:

"I immediately set down to expand my work beside painting to all other necessities, and especially to introduce harmonic singing and physical exercising as the basis for a healthy body and spirit. But much needed to be done to improve the neglected home education" $[\ldots]$ "The physical exercising proceeded difficult in the beginning, because Belgrade populace did not understand the benefits of this, and there was even disapproval."

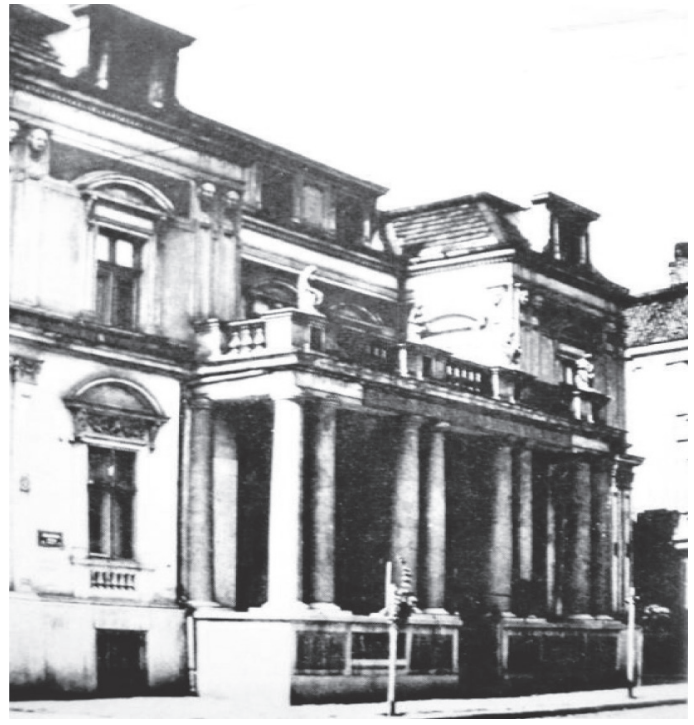

Photo 2. House at Kosančićev venac Street (Belgrade)

He grouped Lyceum students according to their talents and interests, and soon the Company for Gymnastics and Martial Arts was formed, later renamed the First Serbian Association for Gymnastics and Martial Arts (1857). Practising gymnastics and fencing, the Company quickly gained favour and great popularity among the students, and it even received support from Prince Mihailo Obrenović. Young intellectuals who would later hold important positions in Serbian politics, science and education - Vladan Đorđević, Miloš S. Milojević, Milan Kujundžić, Čedomir "Čeda" Mijatović, Ljubomir Kaljević, Steva Popović "Crni“, Andra Nikolić, and others - also practised gymnastics there (Đorđević, 1927; Petrović, 1983).

"Šćeva", as he was nicknamed by his students, endeavoured to diversely educate the youth in a patriotic spirit. He devoted a lot of time to them, beside to his painting, seeing in them the bearers of future changes in Serbia. Šćeva's former student, the writer Čeda Mijatović, later wrote how it had all begun in New Spark in 1900 (Jeftimijades, 1938):

"He taught us to swim in the waves of music, to emerge from them rejuvenated, with our souls cleaner and nobler. However, his workshop soon became to us a true academy for skills, literature, aesthetics and morality. We visited him at any time of day, early in the morning and late in the evening. We stood around him, observing him while he worked and listening to him." [...] "He was jovial, always jocund, witty, spirited..." [...] "One merciful and fortunate thought en- 
sured that this self-sown academy develop and take us to higher planes." [...] "That was when Steva started organising music and aesthetics nights where there would be singing and an issue from literature and aesthetics would be discussed. Practically unintentionally he became our dear and great teacher. When he had realised this himself, then, to make a full circle of our education, he began teaching us drawing and gymnastics. That was how we were fortunate to, from 1857, go for free to a school, which was as priceless as gold, and which had no peer before and after. When Steva had gathered around himself and impressed a significant number of young men, in the autumn of 1857, in conjunction with them, he established a association for physical exercising named The First Serbian Association for Gymnastics and Martial Arts.

\section{THE FIRST SERBIAN GYMNASTICS ASSOCIATION AND GYM}

That 1857 Belgraders were proud that their town was among the first Slavic cities to have its own gymnastic association, and their thanks went to the young academic painter StevanTodorović, who stood in the first ranks of the young Serbian bourgeoisie when cultural societies started being established (Jovanović, 1957). He taught in his workshop, and when the number of students had grown he addressed Belgraders in the press to help him with that useful endeavour. That was how exercising continued in Sava Spahija's warehouse near St. Michael's Cathedral. That was how the first gym in Belgrade came to be.

In spite of objections to these activities from the public, such as a parent report to the police that "such games are being played that children could break arms and legs", Steva managed to deal with these difficulties relying on his connections, since among his students there were also children of important figures. When it came to a one-day ban, the Minister of Education Kosta Nikolajević intervened (Simić, 1951).

From Raspop's house and the small Spahija's warehouse he moved his Painting School into the building of Turkish Han (the nowadays location of the University of Belgrade Rectorate). Soon, on the third day of 1860 Easter, Steva gave the first public lesson in this building. At this demonstration the drawings and aquarelles of Steva and his students were shown, popular and church songs were performed, followed by a demonstration of gymnastic and fencing skills. This public class, of which much was said and written later, had been attended by Prince Mihailo, who expressed to Steva, after the demonstration was over, his "particular pleasure", and delighted with the students' achievements decided to provide Todorović with better working conditions (Simić, 1951).

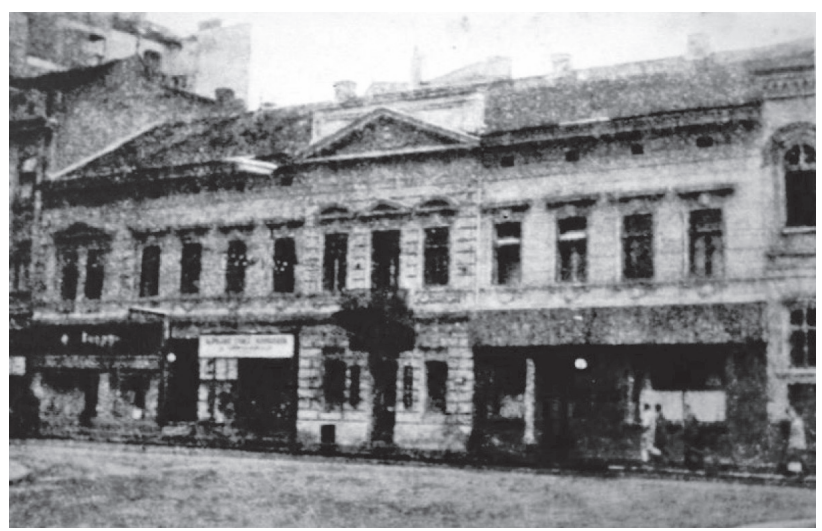

Photo 3. The building of Turkish han (Belgrade)

Encouraged by this success Steva asked the Prince to help him by sending him on a study and professional development trip to Rome, for a year or two. The Prince granted this wish and advised him to wait further instruction in Vienna, but, because of a scheme of a palace administrator Steva did not receive this help, and because he was already in Vienna he spent his savings while waiting for the promised help. He did not lose the desire to learn more even on this occasion, and so he spent time visiting Professor Rahl's school. He lived with "his good friend" Kor-

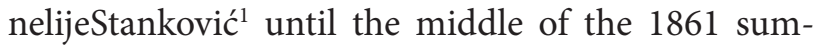
mer, while Jovan Bošković ${ }^{2}$ helped him to find money to return to Belgrade. In Belgrade, he settled in the "Kruna" inn, and after two months he found himself in even greater debt. Since he could not pay the expenses, the innkeeper sold his paintings and equipment in the market.

1 Kornelije Stankovic, the first Serbian educated composer, conductor, pianist, music writer.

2 Jovan Boskovic, at the time professor of Grammar School, linguist, educator at the court of Obrenovic, theater critic, professor of the High School, member of the Serbian Royal Academy, Minister of Education. 


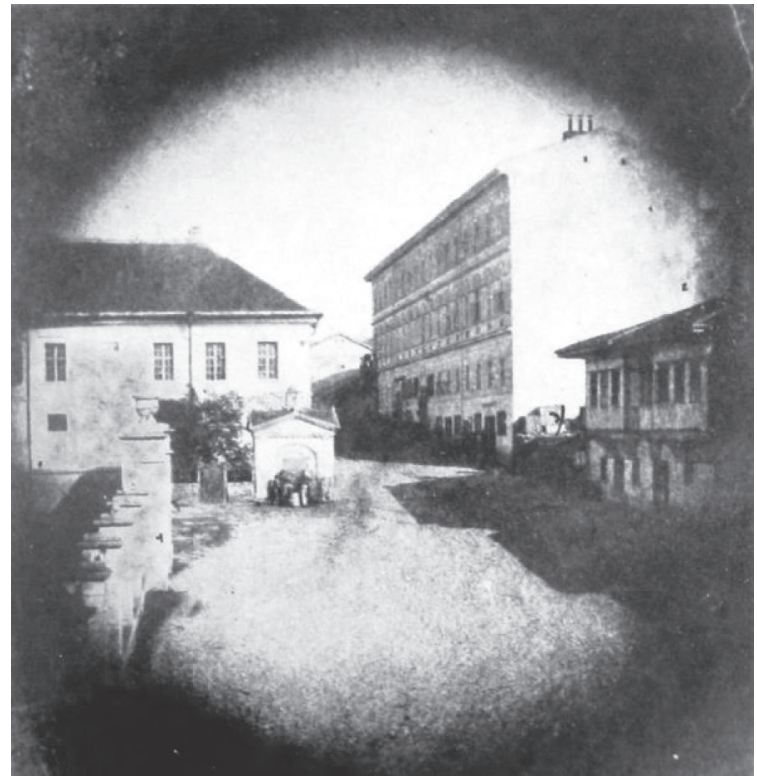

Photo 4. Staro zdanje (name of a building)

\section{ENLIGHTENMENT TROUGH EXERCISING}

Gaining the Obrenović favour, at the beginning of November 1861 Todorović became the tutor to Prince Mihailo's ten-year-old illegitimate son, Velimir Todorović. That was probably one more reason why Steva got a good pay and a large apartment with a balcony and two chambers, for his studio and gym, in the "Staro zdanje" hotel (in the 7. juli St. at the modern day location of the National Bank of Serbia) where he could also place modern gymnastics equipment even in winter. In the summer of 1862, at his own expense, the Prince also built the summer exercising grounds near the Kalemegdan Fortress - across Realka school, at the modern day location of the Serbian Academy of Sciences and Arts - with the most modern exercising equipment (Trujić, 1976). Steva’s gymnastics association operated until 1864. Intensive work in the well-equipped gym and in the exercising grounds in the open continually attracted new members, middle school students, and so the number of students in his School grew to 80 .

At the beginning of 1861 Steva started teaching, beside Velimir, other students chosen by the Prince, and his contract stipulated that this work should last for six years. In his "Staro zdanje" apartment, he taught drawing, singing, gymnastics and fencing, while for other subjects - foreign languages, piano and others - he hired "particular" teachers. In these groups there were even girls. The Prince allowed that
Todorovićs students could be joined in their exercises in the gym and on the summer exercising grounds by high school students. During the summer break, he took the students on study trips to Italy, France and Switzerland, and they kept journals, which would be handed to the Prince upon their return to Serbia. This is what Steva wrote about that:

"The first thing I would do was examine my students' home education and knowledge acquired at school" [...] "It required a great effort on my part to tame these little savages, to form in them the sense for noble deeds, and particularly the love for Serbdom and the fatherland."

Steva marked the beginning of this pedagogical work as a turning point in his life, remembering "the miserable past" and difficult moments from his youth. This all happened at the moment of great dejection due to pennilessness, when he was dependent upon the help of his friend Jovan Bošković, for his life to suddenly become more carefree, filled with acquaintances and recommendations: "And only now did I see what this world is like: now when I had everything in abundance, offers came from all sides even for my dear painting" (Simić, 1951).

Steva also considered a turning point in his life, his marriage to Poleksija Ban, the daughter of the poet and dramatist Matija Ban. Poleksija was one of Steva's students, who charmed him with her talent for painting and her pleasant spirit, though he was also flattered that she was the daughter of a famous poet, writer and politician. Their joint and extensive work would bring him the realisation of great ambitions in painting. The Prince allowed him to stop teaching and unexpectedly rewarded him with a wedding gift of two thousand ducats, and thus helped him to go to a honeymoon. This trip served Steva and Poleksijas further professional development in Florence and Rome, where they copied the works of classical artists - Raphael, Titian, Rubens, Leonardo da Vinci, Michelangelo, Giorgione and others (1864-1865) (Simić, 1951).

In the spring of 1865 Steva accepted the position of the assistant professor for free-hand drawing at the newly founded Technical Faculty of the Belgrade Higher School. In September he was already appointed as the drawing teacher in a Belgrade high school, and after two months he received a permanent employment in Realka (Todorović, 1899). That was how, in spite of considering painting his life's call, Steva would spend his life working as a teacher, from 1865, until 1894, when he was let into retirement at his own request. 


\section{EXERCISING, PATRIOTISM AND "NATURAL KNOWLEDGE" OF STEVAN TODOROVIĆ FROM CULTURE, SCIENCE AND ART}

One hundred and sixty years have passed since StevanTodorović, a visionary and father of cultural and artistic life of the backward Principality of Serbia, arrived from progressive Vojvodinato Belgrade. He immediately shook the languid spirits of the apathetic provincial milieu and continued working passionately on the cultural-educational growth of his fellow Belgraders. He worked tirelessly with his heart full of endless love, with inexhaustible strength of his spirit and body and the faith in the better life and people, giving all of himself so that the values of a better cultural life may take roots among the Serbian people and in their state. He left important, deep and undeniable marks on the social, cultural, artistic and sport life.

Diversely educated, refined, talented, noble, tireless, a patriot, intolerant towards foreigners in the singing societies and theatre, sensitive to the poverty among the people and in the association, generous to his friends, always caring for his "dear" mother... An academic painter, and the teacher of drawing, painting and other skills, the author of critiques and polemics, an actor in his youth, a theatre decorator, a baritone singer, gymnast and fencer. The greatness of his diverse work and contribution to the cultural development of Serbia from the middle of the 19th century, was characterised by rich painting opus, pedagogical work with children and the youth, as well as activities in the founding and development of numerous cultural-artistic and sport institutions and societies.

From this time distance Steva's mental strength and endurance are awe-inspiring. He served diligently in the education system, where he held between 18 and 22 classes a week, always a number of different subjects: free-hand drawing, geometry, Serbian history, the history of trade and crafts, geography, descriptive geometry, ornamnetics, architecture and topography, German language, and on his own accord gymnastics and fencing. He left behind a considerable opus in historical and church painting, portraiture and landscape painting, and also managed a painting, sculpting and gymnastics school, and a fencing department, participating in all cultural-artistic events in Belgrade, travelling abroad on state missions and was quite active in theatre and singing companies.

He participated in politics and was loyal to the Liberal Party. Despite his high social standing, fruitful work and favour of the Obrenović dynasty, due to the rivalry between the Liberal and Progressive parties he felt on his own skin the degradation of the teaching profession. In just a few months of the same year at the "recommendation" of the Minister of Education Kosta Cukić, he was transferred from the Technical Faculty to Realka. In his advanced years he belonged to the higher stratum of the Serbian bourgeoisie, but at the end of the 19th century his work developed outside the ruling circles. In the war with the Ottomans (1876) he stoically shared the fate of Serbian soldiers, as a father and grandfather. In a letter from the front he wrote to his Poleksija that he "was lamenting that he had not arrived to the site of a fierce battle a day earlier" and that "it didn't trouble him that he was sleeping on the ground and that he had felt the blessing of all manner of insects, when he marched with such a brave army" (Simić, 1951). From the front he sent, relying on stagecoaches, drawings for the foreign newspapers and salary paycheques, so that Poleksija and their four children, Zorica, Ljubica, Miloš and Milan, would not be without money.

Serbian art critics consider him one of the most famous and most revered painters of that period and the leading representative of Romanticism in Serbian painting. He held his first exhibition, the first one in Serbia in general, in Belgrade in 1859, and it received the highest praises and excellent criticism. He made around a thousand drawings, genre paintings, portraits, aquarelles, twenty iconostases and historical compositions, and in this he had a great help in his wife Poleksija. He made some 300 representative portraits of his contemporaries, members of the Obrenović dynasty, and a number of writers, scientists, wellknown merchants, chroniclers. In his most fruitful phase (1850-1880), he created famous works, among them a group portrait of Belgrade gymnasts and a self-portrait from 1854 which is one of the most valuable works of Serbian Romanticism (Kusovac et al., 2002). A huge number of Todorovićs works have not been preserved, drawings from the 1876-1878 wars with the Ottomans and from his journeys were stolen in 1918, along with great historical compositions, works from international exhibitions were either ruined or stolen by the enemy during the Great War. 


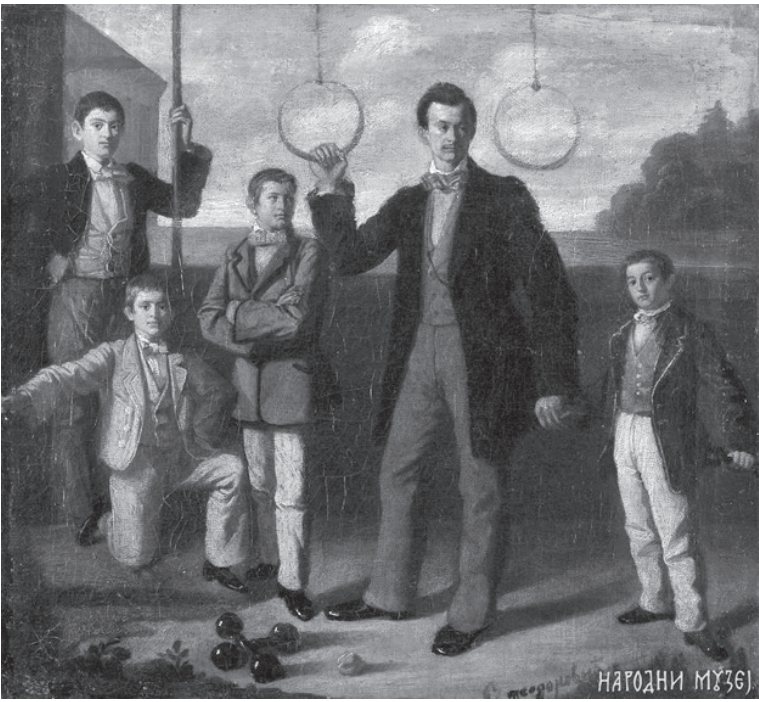

Photo 5. Group portrait of Belgrade gymnastics, 1858-1859.

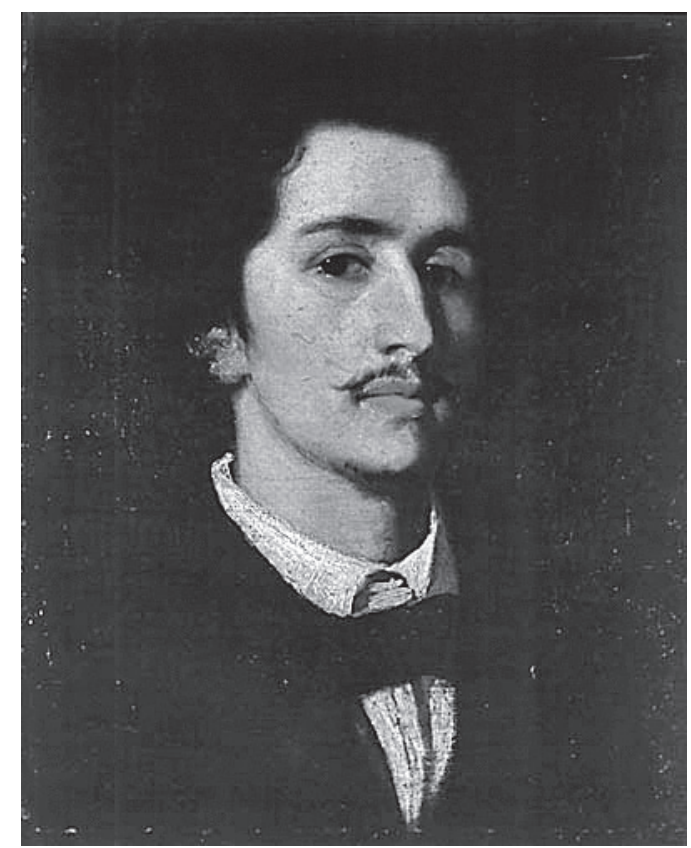

Photo 6. Stevan Todorović - Autoportrait, 1854.

Steva was a tireless cultural worker, significant in the development of music and theatre life of Belgrade which was unparalleled in the Serbian culture of the second half of the 19th century. In 1857 Steva became a member of a Belgrade amateur theatre troupe. He was the manager of the amateur theatre in "Kneževapivara" inn, and in it he acted, directed, made backdrops and decorations, and in various manners participated in 53 plays, until the establishment of the National Theatre where he assisted as a scenographer. Until deep old age he worked on the improvement of vocal music and acting. He was the founder and from 1865 member of the First Belgrade Singing Association for 33 years, a long-time president, and that was why he was elected as the permanent president of this association. In his AutobiographySteva remembers how he diligently worked to remove German, and other foreign actors and singers, from the performance of Serbian songs (Todorović, 1899).

\section{STEVAN TODOROVIĆ - PHYSICAL CULTURE AND ORGANIZED EXERCISING IN SERBIA}

The Autobiography that StevaTodorović wrote in his late years in exile (in 1915 in the town ofVranje, and 1917 in Rome), also encompasses a part of his total engagement in the development of physical culture, and those were activities in the establishment of physical exercising in the Painting School, i.e. in the Company for Gymnastics and Martial Arts, and to a lesser extent, the functions in gymnastics and the Sokol movement. However, enough of relevant source data not included in theAutobiography on Steva's contribution to the development of physical culture in the Kingdom of Serbia has been preserved.

Steva's work in education, which started in 1857, is considered the beginning of the first emergence of organised physical exercising (gymnastics) in Serbia, from which the Sokol movement and modern sports would spring out. From then on, during the coming decades, Steva would be in the centre of all important events in the physical culture of Serbia, almost until the end of his 93-year long and fruitful life. His initial experiences in the development of physical exercising were precious for the further advance of gymnastics and Sokol movement. His students from the Compa$n y$ established and helped, twenty years later, other similar societies in the Kingdom of Serbia. And Steva was, as one of the founders and a functionary in the Belgrade Association for Gymnastics and Martial Arts (1882) - on many occasions the vice president of this association (1882-1884 and 1889-1891); the president (1884-1886 and 1888-1889); and a member of the Managing Board (1882-1891). When Belgrade gymnasts accepted the Czech Sokol System, Steva was still active and performed a number of highest functions: he was the president of the Belgrade Gymnastic Association "Soko" (1906-1909); the president of the unified Association of Sokol Association "Dušan 
the Mighty" (from 1910); the president of the Association of Serbian Sokols (from 1908 until the beginning of the First World War, the so called All-Serbian Sokol Association); a representative of the Serbian Sokol movement in the All-Slavic Sokol Association (from 1910). He was a member of the Committee for the Establishment of the Belgrade Gymnastics School and the Committee for the Gymnastics Exams; he continued helping the founding of gymnastic and Sokol societies throughout Serbia; at his own request he taught gymnastics in Belgrade Realka (1874-1881).

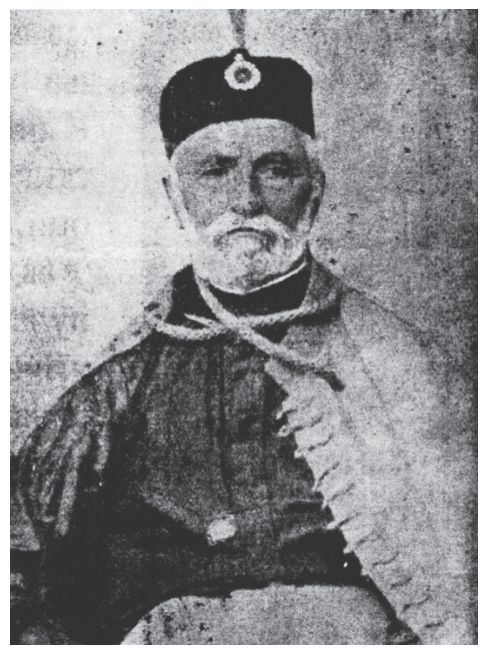

Photo 7. Stevan Todorović in his late years

Beside these managerial activities Todorović participated in the slets of Bulgarian "Junak" in Sofia (1910), Sokols in Zagreb (1911) and Prague at the First All-Slavic Sokol Slet (1912) as a representative of the above mentioned associations. During his war exile in Italy he participated in the founding of the Serbian Football Club "Soko". After the end of the Great War, even though quite old, Todorović was elected to the lifetime positions of honorary president of the Belgrade Sokol Department upon its founding (1920) and honorary head of the Sokol Association of Belgrade-Matica. With these acts Steva received a deserved recognition for the pioneer steps he had undertaken in the organising of physical exercising, and for his long work on the development of gymnastics and Sokol movement in Belgrade, Serbia and farther. "Uncle Steva", as the Sokols later called him, in the sport expert community is mostly known as the founder, and to some, the father of sport in Serbia (Rašić, 1908; Todorović, 1899. and 1912; Jeftimijades, 1938; Simić, 1951; Jovanović, 1957; Todorović, 1968; Trujić, 1976; Ilić i Mijatović, 2006; Vukašinović, 2016).

\section{THE BIOGRAPHY OF STEVAN TODOROVIĆ - ETERNITY OF SERBIAN EXERCISING AND SPORT MOVEMENT}

The enormous and tireless work brought to Steva recognition and material security for a comfortable life in his late years. For everything he had done during his life StevaTodorović was honoured and rewarded. In the Serbian-Ottoman Wars (1876-1878) he was decorated with the Order of the Cross of Takovo of the fourth and third class, as a war painter and newspaper reporter. For his artistic work he was decorated with the Order of Saint Sava of the third and second class, the Order of the White Eagle of the fifth class, and Karađorđe's Star of the fourth class, the Order of Prince Danilo of the fourth class, Order of the Crown of Italy of the second class... He was chosen as an honorary, and not long after, a regular member of the Serbian Royal Academy (1902), the honorary member of the Saint Petersburg Academy of Arts and the Italian Catania Academy. For his contributions to the sport, he also received numerous recognitions. Togymnasts and Sokols, once, and now, Steva has been a pioneer, father, a great man of physical exercising.

StevanTodorvić died on 22 May 1925 and was buried in the Belgrade New Cemetery. For this last farewell to Uncle Steva many people gathered - the common citizenry, official representatives of numerous institutions, artists, actors, singers, and gymnasts, Sokols and sportsmen.

\section{Notes}

At the Faculty of Sport and Physical Education University of Belgrade, on November 3 and 4, 2017, the Scientific Meeting was held „160 years since the beginning of organized physical exercise (1857) and 126 years since the emergence of Sokol movement in Serbia (1891)". Within the program, representatives of the Faculty, members of the Sokol Association of Serbia and Belgrade, Sokol Association Belgrade Matica and participants of the scientific gathering, honored in the gardens of the great ones at the New Cemetery, laid wreaths on the graves to academics Steva Todorović, Dr. Vladan Đorđević and Dr. Vojislav Rasic. At the scientific conference were presented the results of the research on this work, about the life and impressive works of Steve Todorovic. 


\section{REFERENCES}

1. Đorđević, V. (1927). Усйомене, кулӣурне скище из gруіе йоловине 19. века, 1. [Memories, cultural sketches from the second half of 19 century, 1. In Serbian] Novi Sad: knjižara "Slavija“.

2. Ilić, S., and Mijatović, S. (2006). Истиорија физичке кулитуре Кнежевине и Краљевине Србије, gео 3. [History of physical culture in the principality and Kingdom of Serbia, part 3. In Serbian]. Beograd: Fakultet fizičke kulture Univerziteta u Beogradu.

3. Jeftimijades, M. (1938). Čika Steva Todorović. [Uncle Steva Todorović. In Serbian] Oko sokolovo 2, 26-28.

4. Jovanović, В. (1957). Поводом стогодишњице организованог физичког васпитања у Србији. [On the occasion of hundred years of the organised physical education in Serbia. In Serbian]. Physical culture 7-8. 326-332.

5. Kusovac, N., Vrbaški, M., Grujić, V. and Kraut, V. (2002). Stevan Todorović 1832-1925. [Stevan Todorović 1832-1925. In Serbian]. Novi Sad: Narodni muzej Beograd, Galerija Matice srpske.

6. Matić, М. (1975). Родоначелник покрета физичке културе у Србији - Стева Тодоровић. [The Founder of physical culture movement in Serbia - Steva Todorović. In Serbian]. Physical culture, 2. 12-15.

7. Petrović, V. (1927). Todorović Stevan. [Todorović Stevan. In Serbian]. In S. Stanojević (ed.), Narodna enciklopedija, 4. Novi Sad: štamparija Budućnost.

8. Petrović, V. J. (1983). Физичка култура до 1941. год. [Physical culture until 1941. In Serbian]. In M. Maletić (ed.), Sociajalistička republika Srbija, II tom (pp. 429-454). Beograd: Književne novine.
9. Rašić, V. (1908). Spomenica na prvo srpsko sokolsko veče. [Memory on first Serbia Sokol evening. In Serbian]. Beograd.

10. Simić, M. Z. (1951). Autobiografija Steve Todorovića. [Autobiography of Steva Todorović]. Novi Sad: Matica srpska.

11. Todorović, S. (1968). Steva Todorović (1832-1925) i Prvo srpsko društvo za gimnastiku i borenje u Beogradu. [Steva Todorović. In Serbian]. Zbornik za istoriju fizičke kulture Srbije, 2-3, 7-12.

12. Todorović, S. (1899). Autobiografija. [Autobiography. In Serbian]. Godišnjak Srpske kraljevske akademije, 12, 189-207.

13. Todorović, S. (1912). Savez Sveslovenskog Sokolstva. [Union of all Slovenian Sokol. In Serbian]. In S. Obradović (ed.), Sokolski godišnjak za 1911. Beograd: Savez sokolskih društava "Dušan Silni“, 34-37.

14. Trujić, N. (1976). Физичка кулитура у школама Србије у 19. веку. [Physical Culture in schools in Serbia in the 19th century. In Serbian]. Beograd: Komisija za istoriju, arhiv i muzej fizičke kulture Srbije.

15. Vukašinović, V. (2016). Гимнастиика и соколсииво у Србији gо 1941. іолине, великани срйске іимнастиике и соколстива. [Gymnastics and Sokol in Serbia until 1941, great names of Serbian gymnastics and Sokol. In Serbian]. Beograd: University of Belgrade, Fakultet sporta i fizičkog vaspitanja.

\title{
LEBEN UND WERK DES TURNERS, KÜNSTLERS, AUFKLÄRERS UND BEGRÜNDERS VON ORGANISIERTEM SPORT IN SERBIEN STEVAN TODOROVIĆ
}

\begin{abstract}
Zusammenfassung
Im Jahr 2017 wurden 160 Jahre seit Beginn von organisierten körperlichen Übungen (1857) und 126 Jahre seit der Erscheinung der Sokolbewegung (1891) in Serbien gefeiert. Evoziert wurde der riesige Beitrag, den der Akademiker Steva Todorović, dr. Vladan Đorđevic und dr. Vojislav Rašić zu den Anfängen und der Entwicklung von Körperkultur im Fürstentum und Königtum Serbien geleistet haben. Es wurden 160 Jahre seit der Ankunft des Akademikers Stevan Todorović in der Hauptstadt Belgrad gekennzeichnet, in der er 1857 seine kulturelle und aufklärerische Arbeit begann. Im Rahmen der Malerschule, die er eröffnete, wurde eine „Genossenschaft für Gymnastik und Kampfsport" als erste organisierte Gesellschaft für körperliche Übungen gegründet. Diese Genossenschaft war ein Vorgänger für die Akzeptanz der Sokolbewegung, die Entwicklung des modernen Sports und die Affirmierung von Körperkultur in Serbien. Ziel dieser Arbeit ist es, den Beitrag des Akademikers Stevan Todorović zum insgesamten Progress von Kultur, Bildung und Körperkultur zu erleuchten. Durch eine historische Methode wurden authentische Dokumente aus den Jahren 1899, 1908, 1912, 1927, 1938 bearbeitet, die der breiteren und fachlichen Öffentlichkeit und Mitgliedern von Gymnastik- und Sokolvereinen nicht zugänglich waren.
\end{abstract}

Schlüsselwörter: STEVAN TODOROVIĆ / KÖRPERKULTUR / BILDUNG / KULTUR / KUNST / SERBIEN

Received: 05. 11.2017. Accepted: 06. 12. 2017. 


\title{
СТЕВАН ТОДОРОВИЋ, ЖИВОТ И ДЕЛО ВЕЖБАЧА, УМЕТНИКА, ПРОСВЕТИТЕЉА И ЗАЧЕТНИКА ОРГАНИЗОВАНОГ СПОРТА У СРБИЈИ
}

\author{
Владан Вукашиновић
}

Универзитет у Београду, Факултет спорта и физичког васпитања, Србија

\begin{abstract}
Сажетак
У 2017. години обележено је 160 година од почетка организованог телесног вежбања (1857) и 126 година од појаве соколства у Србији (1891). Евоциран је огроман допринос академика Стеве Тодоровића, др Владана Ђорђевића и др Војислава Рашића, почетку и развоју физичке културе у Кнежевини и Краљевини Србији. Обележено је и 160 година од доласка академика Стевана Тодоровића у престони Београд, у коме је 1857. године започео свој културни и просветитељски рад. При „Сликарској школи“ коју је отворио, оформљена је и „Дружина за гимнастику и борење“, као прво организовано друштво за телесно вежбање. Ова Дружина је претходила прихватању „Соколства“, развоју модерног спорта и афирмацији физичке културе у Србији. Циљ овог рада је да се осветли допринос академика Стеве Тодоровића укупном културном и образовном напретку Србије, укључујући физичку културу. Историјским методом су обрађена аутентична документа из 1899, 1908, 1912, $1927,1938$. која нису била доступна и позната широј и стручној јавности, гимнастичком и соколском чланству.
\end{abstract}

КљУчне речи: СТЕВАН ТОДОРОВИЋ / ФИЗИЧКА КУЛТУРА / ОБРАЗОВАњЕ / КУЛТУРА / УМЕТНОСТ / СРБИЈА

\section{УВОД}

Међу истакнутим поборницима телесног вежठања у Србији, који се и данас, после временске дистанце веће од једног века, сматрају харизматичним визионарима гимнастичког и соколског вежठања, убрајамо Владана Ђорђевића, Војислава Рашића, Лазу Поповића, Мирослава Војиновића... Али, овом скупу знаменитих зачетника теловежбеног покрета мора се придружити, као први утемељивач, још један великан српске гимнастике и соколства - а то је Стеван „Стева“ Тодоровић (Вукашиновић, 2016). Први је, и на свој начин, оставио неизбрисив траг и утиснуо снажан печат на покретање организованог физичког вежбања и оснивање и развој грађанских гимнастичких и културних друштава у оквиру друштвено-културних промена у Србији од средине 19. и почетком 20. века ${ }^{1}$.

1 На Факултету спорта и физичког васпитања - Универзитета у Београду, 3. и 4. новембра 2017. године, одржан је

\section{СТЕВАН ТОДОРОВИТ - ЖИВОТОПИС МЛАДОГ ВЕЖБАЧА}

Стеван Тодоровић (13.04.1832, Нови Сад 22.05.1925, Београд), пореклом је Херцеговац. Отац Јован из Требиња, херцеговачки устаник, војевао је седам година, од своје деветнаесте године, док није лакше рањен. Када су Турци 1813. ударили великом силом на устанике, спасао се прешавши Саву на аустријску страну у Бежанију код Земуна. Игром случаја ту је затекао и родите-

\footnotetext{
Научни скуп „160 година од почетка организованог телесног вежбања (1857) и 126 година од појаве соколства у Србији (1891)". У оквиру програма, представници Факултета, чланови Соколских савеза Србије и Београда, Соколског друштва Београд Матица и учесници научног скупа, у алеји великана на Новом гробљу, одали су почаст и положили венце на гробове академику Стеви Тодоровићу, др Владану Ђорђевићу и др Војиславу Рашићу. На Научном скупу изложени су резултати истраживања овог рада, о животу и импозантним делима Стеве Тодоровића.
} 
ље и одатле се сви пресељавају у Нови Сад, где отпочињу да раде са турским дуваном. Мајка Јелена, родом из Белог Потока под Авалом, у сродству по женској страни са Васом Чарапићем, пребегла је такође са родитељима из Србије у Нови Сад где ће наставити успешно да тргују (Симић, 1951).

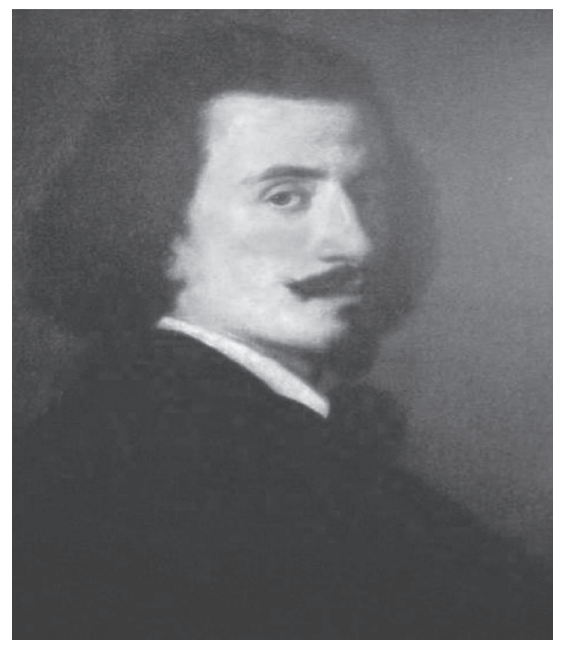

Слика 1. Стеван Тодоровић

Стеван је рођен у Новом Саду, у породици са седморо деце, четири сина и три кћери. Трговина са дуваном доносила је породици добар приход до 1937, када су и радња и стан изгорели у великом пожару. Стеван је уписао основну школу у Новом Саду, али од седме године живи у Сегедину где су родитељи откупили радњу са топлим и хладним купатилом на Тиси. Од 1839. до 1846. године похађао је у Сегедину основну школу и пет разреда гимназије. Стева је у Српској основној школи, коју је издржавала Српска црквена општина, усвојио леп стил писања по Вуковом правопису од учитеља ђакона Димитрија Поповића. Васпитни утицај учитеља, познатог по томе што је био брат од стрица Ђуре Даничића и Вуков саборац за српски језик и правопис, био је огроман током школовања на обдареног и свестраног Тодоровића (Симић, 1951). На Стеванов животни пут имао је огроман утицај и познати учитељ гимнастике и борења у сегединској гимназији Ђорђе Марковић Кодер (Тодоровић, 1968). Млади гимназијалац био је одушевљен вештинама гимнастике и мачевања и то ће бити веома значајно за формирање Тодоровићеве личности, а што ће се у будућности потврдити.

Средином 1846. отац га води на даље школовање у Беч и тамо завршава шести и седми разред гимназије. После матуре уписује се на Лицеј, на коме слуша филозофију. Када је избила револуциja 1848, силом прилика ступио је у ђачки одред, што му је омогућавало да се прехрани, јер је у ратним приликама веза са породицом била прекинута, и посебно јер му је отац, исте године, нешто раније умро, а да није знао.

После слома револуције Стева се враћа из Беча 1849 , одлази у Београд код стрица, његовог стараоца за школовање. У његовој пивари учи производњу пива, али сваки слободан тренутак „црта и слика воденим бојама, сви зидови испуњени су његовим радовима“. Стриц увидевши Стевин таленат и његову од детињства једину жељу - да се бави сликарством, одводи га у Беч и уписује у други семестар Сликарске академије (живописа) 1850.

Животне околности у младости нису биле наклоњене лицејцу Тодоровићу, али је током школовања крчио себи пут без обезбеђене стипендије. Шест недеља после уписа Академије умире му стриц и Стева губи месечну помоћ од 150 форинти. У Београд се враћа и као наследник по стричевом тестаменту и затиче опљачкану и разграбљену стричеву кућу. Убрзо, банкар и градски паша одузимају му кућу са земљиштем и пивару, а превару је смислио Стевин адвокат бранилац. По повратку у Беч Стева уписује приватну школу професора Валдмилера. Помоћ мајке није била довољна за школовање и приморан је да се до краја 1852. издржава од давања приватних часова цртања и певања. Нераздвојни друг Корнелије Станковић, са којим је становао, подучавао га је певању, јер га је красио диван баритон и у Бечу су му док је студирао предлагали да упише оперско певање (Симић, 1951).

Ово је тежак период за Стеву, без прихода враћа се исцрпљен код мајке у Сегедин, потом одлази најпре у Беч, и затим уписује Академију у Минхену (крајем 1853), али се опет због несташице новца, после девет месеци, враћа у Беч на студије (1854) код чувеног професора Карла Рала. У међувремену, опет остаје без новца и враћа се у Сегедин да обиђе мајку и заради за наставак студија. Радио је портрете у више места Војводине и одлази у Нови Сад (у јесен 1855) где проводи десет месеци. Са професорима Српске гимназије Ђорђем Натошевићем, Јованом Гавриловићем и Јованом Ђорђевићем вежба гимнастику и мачевање у гимназијском гимнастичком одељењу и ту 
размењују мишљења о значају вежбања. У пролеће 1856. прикључује се Корнелију Станковићу да би га пратио као „соноран“ баритон на његовим концертима по већим местима и од прихода од концерата добија трећину за наставак студија. Стева је већ познат баритон који „на концертима увек одушевљава“, и у јесен 1856. приређује у Београду врло успео концерт, „када га први пут упознаје цео културни Београд“. Још једном одлази у Беч и у школи професора Карла Рала остаје до краја априла 1857. године, упамћен као најуспешнији међу првим српским сликарима (Тодоровић, 1899; Јефтимијадес, 1938; Симић, 1951).

\section{СТЕВАН ТОДОРОВИК, ВЕЖБАЧ И УЧИТЕЉ ГИМНАСТИКЕ, БОРЕЊА И ПЕВАЊА}

Стева је током усавршавања у Минхену вежбао и гимнастику и мачевање, где је могао непосредно да упозна систем немачке турнернерске гимнастике, као и организацију и методику рада у приватним заводима за вежбање. Вероватно се тамо и родила идеја да по повратку у Србију оснује слично друштво. Предодређен за шире вокациje, Тодоровић је имао и друга интересовања. Док је студирао у Бечу, у круговима напредне српске омладине водио је разговоре о „култури која недостаје нашем народу“, „васпитном значају уметности, телесног вежбања, музике, песме, и позоришта“ као и о националним задацима младе српске интелигенције „која ће се жртвовати због будућих нараштаја“ (Симић, 1951), како би се ухватио корак са напредним европским народима.

Следеће године Стева се доживотно настањује у Београду (мај 1857), и како је био предузимљив одмах отвара Сликарску школу на Косанчићевом венцу, у кући познатог иконографа Милије Марковића Распопа. У свом приватном „заведенију“ бесплатно лицејце подучава цртању, сликању, певању, тумачи им Хомерову Илијаду, декламује Шекспирове трагедије, и како је велики поклоник телесног вежбања, учи их и гимнастику и мачевање. У Аутобиографији Стева је о свом тадашњем ентузијазму записао:

„Прионуо сам одмах да поред сликарства разгранам свој рад и на остале преке потребе, а нарочито одмах да заведем хармонично певање и телесно вежбање као основу здравог тела и здравог духа. Али је много ваљало предузети да се поправи занемарено домаће васпитање“. [...] "Са телесним вежбањем ишло је у почетку теже, јер београдско становништво није схватало благодет ове установе, шта више наступило је и негодовање“.

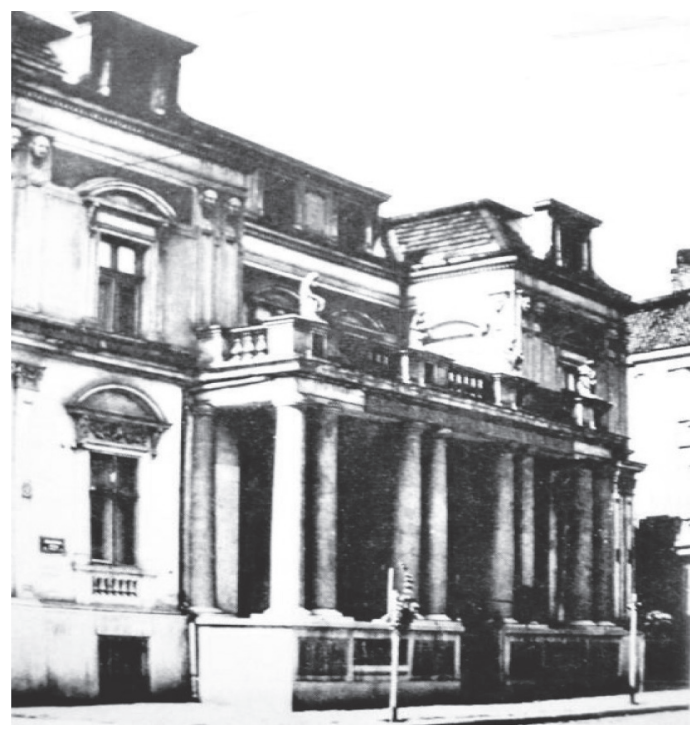

Слика 2. Кућа на Косанчићевом венцу

Лицејце је груписао према талентованости и интересовањима, па се убрзо оформила Дружина за ичинасиику и бореюе, названа Прва сриска gружина за іимнастиику и борене (1857). Дружина је вежбајући гимнастику и мачевања брзо стекла симпатије и велику популарност код ђачке омладине, имала је и подршку од кнеза Михаила Обреновића. У њој су „гимнастисали“ и млади интелектуалци који ће касније заузимати значајне положаје у Србији, у политици, науци и просвети: Владан Ђорђевић, Милош С. Милојевић, Милан Кујунџић, Чедомиљ Чеда Мијатовић, Љубомир Каљевић, Стева Поповић - Црни, Андра Николић и др. (Ђорђевић, 1927; Петровић, 1983).

„Шћева“, како су га од миља звали његови ученици, настојао је да се омладина свестрано просвећује и васпитава у патриотском духу. Поред сликарства посвећивао им је много времена, видевши у њима будуће носиоце промена у Србији. О томе како је све почело писао је касније, у Новој Искри 1900. године, некадашњи Шћевин ђак књижевник Чеда Мијатовић (Јефтимијадес, 1938):

„Учио нас је да у таласима од музике пливамо, да из њих излазимо окрепљени с душом чистијом и племенитијом. Али ускоро је његова радионица постала за нас права академија 
за вештине, књижевност, естетичност и морал. Ми смо му долазили у свако доба и по цео дан, рано у јутро и позно у вече. Стајали смо око њега, гледали га како ради и слушали га“. [...] „Био је весео, свагда ведар, пун досетљивости, пун духа...“ [...] „Једна милостива и срећна промисао постарала се да се ова самоникла академија развија и да нас изводи на све више равнине“. [...] „Стева је тада узео приређивати музикалне и естетичне вечери на којима се певало и дискутовало по какво питање из књижевности и естетике. Тако рећи и нехотице он је постао наш мили и велики учитељ. Кад је већ и сам увидео тај факат, онда, да би заокружио наше васпитање, он нас је почео учити цртању и гимнастици. Тако смо ми од 1857. године били срећни да бесплатно пролазимо кроз једну школу, која је злата вредила, и којој ни пре тога ни после тога равне било није. Када је на тај начин Стева прикупио око себе и одушевио известан број омладинаца, у договору са њима оснује у јесен 1857. године друштво за телесно вежбање, под именом: Прво срӣско ярушйво за іимнастиику и борене.

\section{ПРВО СРПСКО ГИМНАСТИЧКО ДРУШТВО И ВЕЖБАОНИЦА}

Те 1857. године Београђани су поносни сазнањем да је њихов град први међу свим словенским градовима који има гимнастичко друштво, и захвални су на томе младом академском живописцу Стевану Тодоровићу, који је стао у прве редове младе српске буржоазије када су почела да се оснивају културна друштва“ (Јовановић, 1957). Часове је држао у својој уметничкој радионици, и када је број ученика нарастао обратио се Београђанима путем дневне штампе да помогну овај користан подухват. Тако је вежбање настављено у магази Саве Спахије код Саборне цркве. Тако је настала прва вежбаоница у Београду.

Упркос противљењима овом раду у јавности, као што је тужба родитеља полицији да се „заводи таква игра у којој деца могу сломити ноге и руке“, Стева је излазио на крај са овим тешкоћама користећи везе, пошто је међу вежбачима било и деце угледних личности. У случају једнодневне забране рада, интервенисао је министар просвете Коста Николајевић (Симић, 1951).
Из Распопове куће и тесне Спахијине магазе Сликарску школу преселио је у зграду Турског хана (место данашњег Ректората Београдског универзитета). Убрзо, у овом здању Стева је приредио јавни час, на трећи дан Ускрса 1860. године. На овом прегледном испиту рада Стевиног и његових ученика били су изложени цртежи и акварели ученика, певане су народне и црквене песме и изведене су гимнастичке и мачевалачке вештине. Јавном часу, о коме се после пуно причало и писало, присуствовао је и кнез Михаило, који је по свршеном испиту Стеви „изјавио особито задовољство“, и одушевљен знањем ученика решио да Тодоровићу омогући боље услове за рад (Симић, 1951).

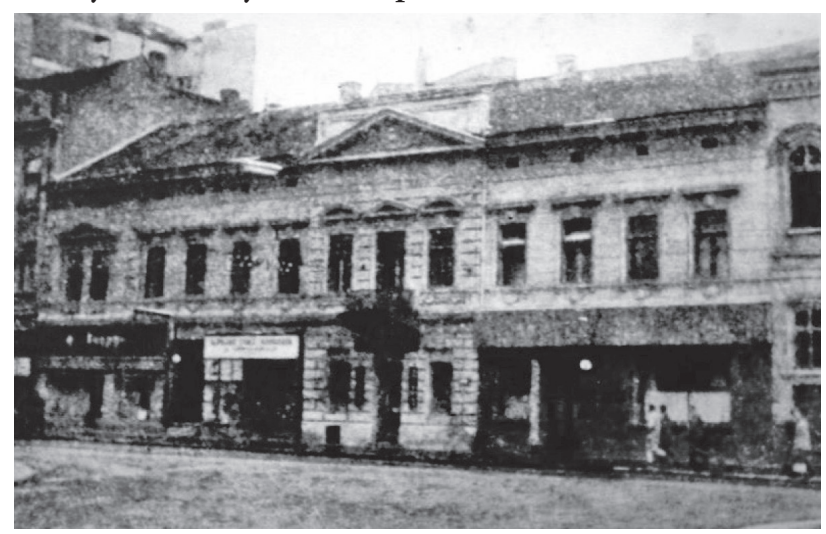

Слика 3. Зграда Турски хан

Охрабрен овим успехом Стева је замолио кнеза да му помогне и омогући студијско путовање на усавршавање у Риму, на годину-две. Кнез је одобрио и посаветовао га да чека даље инструкције у Бечу, али, због сплетке дворског управитеља помоћ је изостала, а Стева се већ нашао у Бечу и чекајући помоћ потрошио уштеђевину. Жеља за усавршавањем није га минула ни овом приликом, па је посећивао школу професора Рала. Становао је код „свог доброг друга“" Корнелија Станковића ${ }^{2}$ до средине лета 1861, а Јован Бошковић ${ }^{3}$ помогао му је да дође до новца за повратак у Београд. У Београду је отсео у „Круни“, и после два месеца запао у још већ дуг. Пошто није могао да подмири трошкове станарине, гостионичар му је продао сликарске радове и опрему на пијаци.

2 Корнелије Станковић, први српски школовани композитор, диригент, пијаниста, музички писац.

3 Јован Бошковић, у то време професор гимназије, лингвиста, васпитач на двору Обреновића, позоришни критичар, професор Велике школе, члан Српске краљевске академије, министар просвете. 
Стекавши наклоност Обреновића, Тодоровић је почетком новембра 1861. постао васпитач десетогодишњег ванбрачног сина кнеза Михаила, Велимира Тодоровића. То је вероватно био још један разлог да Стева од кнеза добије добру плату и велики стан са балконом и две сале, за атеље и гимнастику, у „Старом здању“ (у улици „7. јули“, испод зграде Народне банке) у коме је могао да смести и модерне справе за вежбање зими. О свом трошку кнез је у лето 1862. саградио и летње вежбалиште код Калемегдана (преко пута Реалке, на месту где је данас Академија наука) са најмодернијим справама за вежбање (Трујић, 1976). Стевино гимнастичко друштво било је активно до 1864, интензиван рад у добро уређеној вежбаоници и на отвореном вежбалишту привлачио је непрестано нове чланове средњошколце, па је број ученика Школе нарастао на преко 80.

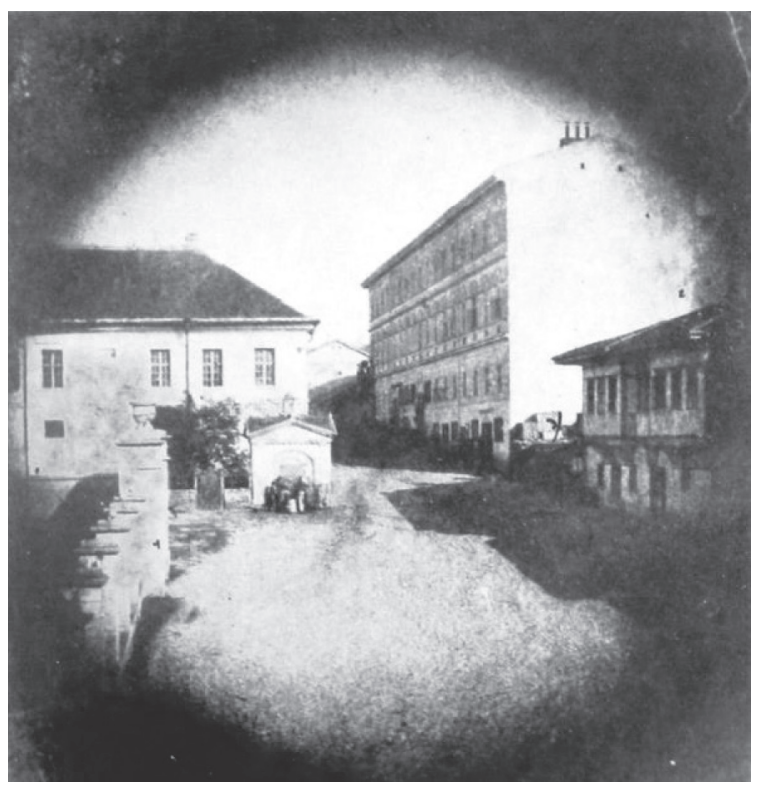

Слика 4. Старо здање

\section{ПРОСВЕТИТЕЉСТВОМ КРОЗ ВЕЖБАЊЕ}

Почетком новембра 1861. Стева је почео да васпитава, поред Велимира, и друге ученике по кнежевом избору, уговор је предвиђао овај рад на шест година. У стану Старог здања предавао је цртање, певање, гимнастику и мачевање, а за друге предмете, стране језике, клавир и др. ангажовао је „нарочите“ учитеље. У овим групама било је и женске деце. Кнез је одобрио да у сали и на летњем вежбалишту са васпитаницима вежбају и ђаци из гимназије. За време летњег распуста водио је ученике на студијска путовања по градовима Италије, Француске, Швајцарске, а они су водили дневнике, који су по повратку подношени кнезу. О томе Стева је написао:

„Прво ми је било да познам код мојих ученика њихово домаће васпитање, као и школско знање“ [...] „Много ми је труда требало да ове мале дивљаке припитомим, да развијем у њима осећај за племените поступке, а нарочито осећај љубави према српству и отаџбини“.

Почетак овог педагошког рада Стева је оценио великом прекретницом у животу, сећајући се „ојађене прошлости“ и тешких тренутака у младости. Одиграо се у тренутку безизлазног положаја због велике беспарице, препуштеног помоћи свог пријатеља Јована Бошковића, да би његов живот одједном постао безбрижнији, испуњен познанствима и препорукама: „И сад сам тек видео какав је овај свет: сад кад сам имао свега у изобиљу, са свију страна се јавише понуде и у мом милом сликарству“ (Симић, 1951).

Стева је и венчање са Полексијом Бан, ћерком песника и драмског писца Матије Бана, сматрао преокретом у животу. Полексија је била једна од Стевиних ученица, која га је освојила талентом за сликарство и пријатном појавом, али му је и ласкало што је ћерка чувеног песника, књижевника и политичара. Њихов заједнички веома обиман рад ће му донети остварење великих амбиција у сликарству. Кнез му је одобрио прекид васпитавања ученика и поклонио неочекивано велики свадбени дар, две хиљаде дуката, којим га је наградио и помогао да остваре свадбено путовање. Ово путовање је било њихово студијско усавршавање у Фиренци и Риму, копирали су дела старих класичних уметника Рафаела, Тицијана, Рубенса, Леонарда да Винчија, Микеланђела, Ђорђона и др. (1864-1865) (Симић, 1951).

У пролеће 1865. Стева је прихватио место доцента за слободно цртање на Техничком факултету новоосноване Велике школе. Већ у септембру постављен је за професора цртања у београдској гимназији, а после два месеца премештен је за стално у Реалку (Тодоровић, 1899). Тако ће Стева, иако је сликарство сматрао својим првим позивом, цео свој радни век провести као педагог, од 1865. до 1894, када је пензионисан на личну молбу. 


\section{ВЕЖБАЊЕ, ПАРТИОТИЗАМ И „ПРИРОДНО ЗНАЫЕ“ СТЕВАНА ТОДОРОВИТА ИЗ КУЛТУРЕ, НАУКЕ И УМЕТНОСТИ}

Стошесдесет година прохујало је од како је Стеван Тодоровић, визионар и утемељивач културног и уметничког живота заостале Кнежевине Србије, дошао у престони Београд из врло напредне Војводине. Одмах је заталасао успаване духове учмалог паланачког миљеа и надаље стрпљиво радио на културно-просветном уздизању својих суграђана. Радио је неуморно срцем пуним безграничне љубави, неисцрпном снагом духа и тела и вером у бољи живот и људе, давао је све од ceঠе не би ли се вредности бољег културног живота укорениле у народу и држави. Оставио је важне, дубоке и неизбрисиве трагове у друштвеном, културном, уметничком и спортском животу.

Свестрано образован, културан, талентован, племенит, неуморан, патриота и родољуб, нетрпељив према странцима у певачким друштвима и позоришним комадима, осетљив на немаштину у народу и друштву, издашан према пријатељима, увек брижан према „милој“ мајци... Академски сликар, и наставник цртања, сликања и бројних дисциплина, писац критика и полемика, у младости глумац, позоришни декоратер, певач баритониста, гимнастичар и мачевалац. Сву величину његовог свестраног стваралаштва и доприноса културном напретку Србије од средине 19. века, карактерише богат сликарски опус, педагошки рад са децом и омладином, као и утемељивачке активности у оснивању и развоју бројних културно-уметничких и спортских институција и друштава.

Са ове временске дистанце запрепашћује Стевина ментална снага и издржљивост. Ревносно је службовао у школи, где је предавао 18 до 22 часа недељно, увек по више предмета: слободно цртање, геометрију, историју Срба, историју трговине и заната, земљопис, нацртну геометрију, орнаментику, архитектуру и топографију, немачки језик, и својевољно гимнастику и мачевање. Остварио је импозантан сликарски опус у историјском и црквеном сликарству, портретима и пејзажима, уз то водио је сликарску, вајарску и гимнастичку школу, руководио мачевалачком секцијом, учествовао у свим културно-уметничким догађајима града, одлазио у иностранство по државним задацима и био врло активан у позоришту и певачким дружинама.

Бавио се политиком и био је одан либералној странци. 3бог ривалитета либерала и напредњака, и поред афирмације, плодног рада и наклоности династије, осетио је на својој кожи деградацију наставничког звања. За само неколико месеци у истој години на „препоруку“ министра просвете Косте Цукића, са факултета је премештен у Реалку. У зрелим годинама припадао је вишем друштвеном слоју српске буржоазије, али крајем 19. века његова стваралачка активност развија се ван владајућег круга. У рату са Турцима (1876) стојички је делио судбину српског војника, као деда и отац. У писму са бојишта својој Полексији пише да „жали што није стигао дан раније на место борбе која је била врло жестока“ и да „не мари што спава на земљишту и што је осетио благодет свих могућих инсеката, кад са тако храбром војском иде“. (Симић, 1951). Са фронта је слао, по дилижанси, цртеже за иностране новине и признанице од плате, како Полексија и четворо деце, Зорица, Љубица, Милош и Милан, не би остала без новца.

Наши ликовни критичари сматрају га једним од најпознатијих и најпризнатијих сликара оног доба и водећим носиоцем српског романтизма у сликарству. Своју прву уметничку изложбу, прву у Србији уопште, приредио је у Београду 1859, која је понела највише оцене и сјајне критике. Урадио је око хиљаду цртежа, жанр слика, портрета, акварела, двадесет иконостаса и историјских композиција, и у томе је имао огромну помоћ супруге Полексије. Насликао је око 300 репрезентативних портрета савременика те епохе, представника династије Обреновић, као и многих књижевника, научника, познатих трговаца, хроничара. У његовој најполетнијој фази (између 1850. и 1880), створио је позната дела, међу њима и групни портрет београдских гимнастичара и аутопортрет из 1854. који је једно од највреднијих дела српског романтизма (Кусовац и др. 2002). Огроман део Тодоровићевих радова није сачуван, цртежи из ратова 1876-1878. и са путовања покрадени су 1918, и велике историјске композиције и радови са иностраних изложби пропали су у рату или је покрао непријатељ. 


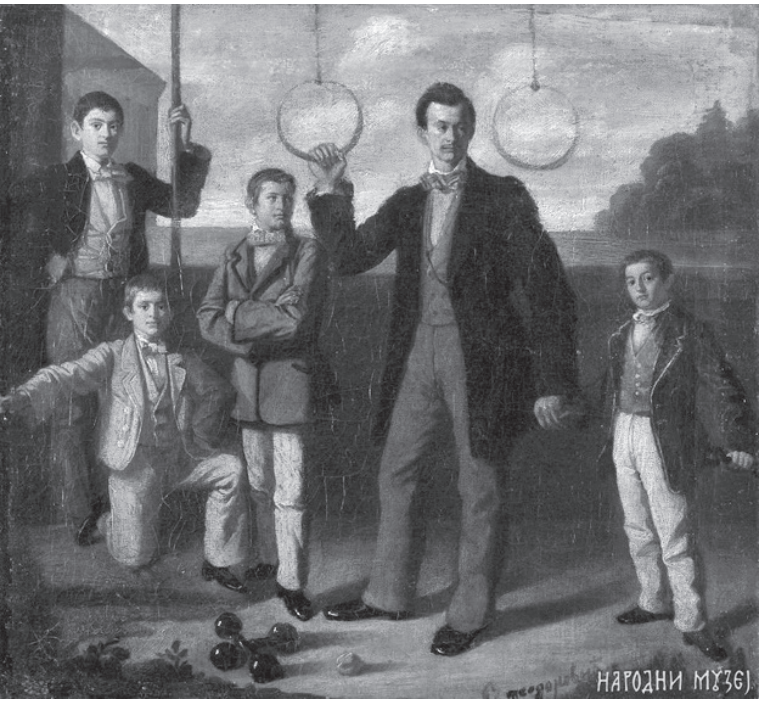

Слика 5. Групни портрет београдских гимнастичара, 1858-1859.

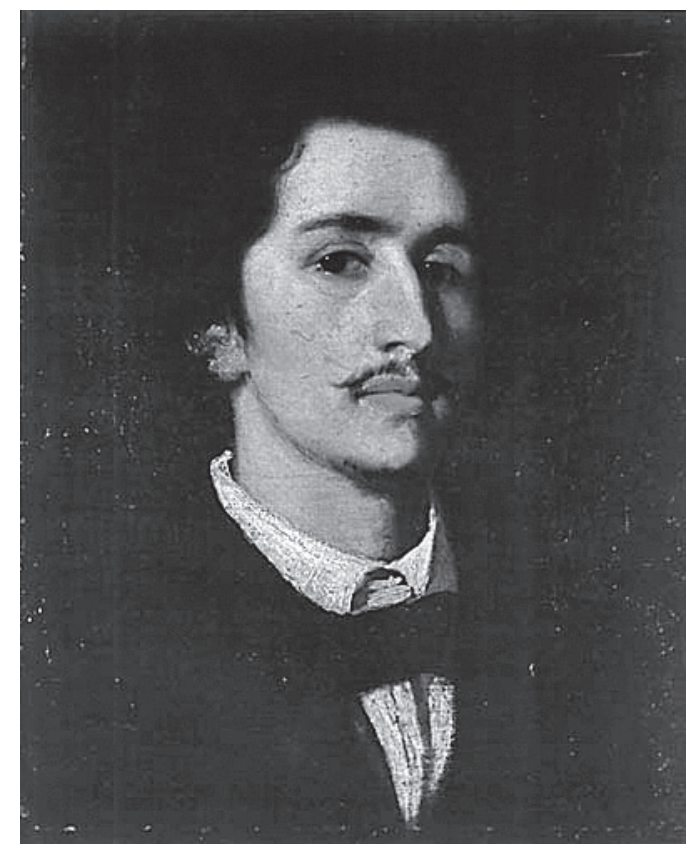

Слика 6 Стева Тодоровић - аутопортрет, 1854.

Стева је био неуморан културни радник, заслужан и у развијању музичког и позоришног живота Београда коме није било премца у српској култури у другој половини 19. века. Још 1857. Стева је постао члан београдске дилетантске позоришне трупе. Био је управник аматерског позоришта у Кнежевој пивари, у њему је играо, режирао, правио кулисе и декорације, и на различите начине учествовао у 53 представе, све до оснивања Народног позоришта у коме је помагао као сцено- граф. До дубоке старости радио је на обогаћивању вокалне музике и глуме. У Првом београдском певачком друштву био је оснивач и од 1865 . године члан 33 године, и дугогодишњи председник, зато је биран за доживотног председника овог друштва. У Аутобиографији Стева се присећао како је упорно радио да српским песмама истисне немачке, као и стране глумце и певаче (Тодоровић, 1899).

\section{СТЕВАН ТОДОРОВИТ - ФИЗИЧКА КУЛТУРА И ОРГАНИЗОВАНО ВЕЖБАҢЕ У СРБИЈИ}

У Аутобиографији коју је Стева Тодоровић писао у позним годинама у избеглиштву (1915. у Врању и 1917. у Риму), обухваћен је мањи део његовог укупног ангажмана у развоју физичке културе, а то су активности на покретању телесног вежбања у оквиру Сликарске школе, односно, Дружине за іимнастикку и бореюе и, у ужем обиму, функције у гимнастици и соколству. Ипак, сачувано је довољно релевантних изворних података који Аутобиографијом нису обухваћени, о Стевином доприносу у развоју физичке културе у Краљевини Србији.

Стевин просветитељски рад, започет 1857. године, сматра се првом појавом организованог телесног вежбања (гимнастике) у Србији, из ког ће се изнедрити и соколство и модерни спортови. Од тада, и наредних деценија, Стева ће бити у средишту свих важних дешавања у физичкој култури Србије, готово до краја његовог 93 године дугог и плодног живота. Почетна искуства у развоју телесног вежбања била су драгоцена за даљи развој гимнастике и соколства. Његови ученици из Дружине, двадесетак година касније, оснивали су и помагали друга слична друштва у Краљевини Србији. А Стева је један од оснивача и носилац функција у Беоіраяском gрушитву за іимнастиику и

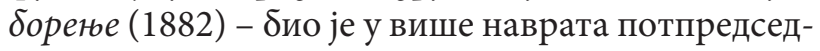
ник овог друштва (1882-1884. и 1889-1891); председник (1884-1886. и 1888-1889); и члан Управног одбора (1882-1891). Када су београдски гимнастичари прихватили чешки соколски систем, Стева је и даље активан и обавља бројне, највише функције: председник је Беоіраяскоі їимнастичикоі̄ gрушішва „Соко“ (1906-1909); председник уједињеног Савеза соколских ярушйава "Душан Силни”(од 1910. године); председник Савеза сритских 
соколова (од 1908. до почетка Првог светског рата, тзв. Свесрйскої соколскоі савеза); представник је свесрпског соколства у Свесловенском соколском савезу (од 1910). Био је члан Комисије за оснивање Гимнастичке школе у Београду и Комисије за полагање испита; наставио је да помаже оснивање гимнастичких и соколских друштава широм Србије; на свој захтев био је учитељ гимнастике у београдској Реалци (1874-1881).

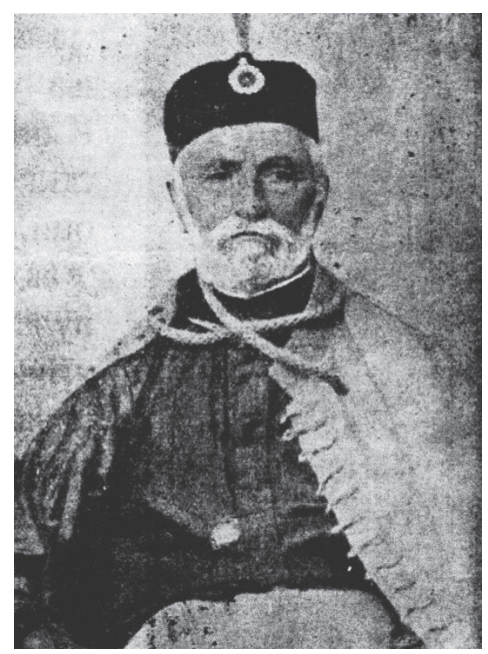

Слика 7. Стева Тодоровић у позним годинама

Поред ових руководећих активности Тодоровић је као представник поменутих савеза учествовао на слетовима бугарског „Јунака“ у Софији (1910), сокола у Загребу (1911) и у Прагу на Првом свесловенском соколском слету (1912). За време Првог светског рата, у избеглиштву у Италији, учествовао је у оснивању Српског лоптачког клуба „Соко“. По завршетку Великог рата, Тодоровић је, иако у дубокој старости, приликом оснивања Беоіраяске соколске жуйе (1920) изабран за почасног доживотног председника, и у Соколском друштву Беоіраg-Майица - за доживотног почасног старешину. Тиме је Стеви одато заслужено признање за пионирске кораке у организовању телесног вежбања, и за дугогодишњи рад на ра- звоју гимнастике и соколства у Београду, Србији и шире. Чика Стева, како су га касније звали соколи, спортској стручној јавности углавном је познат као зачетник, а по некима родоначелник спорта у Србији (Рашић, 1908; Тодоровић, 1899. и 1912; Јефтимијадес, 1938; Симић, 1951; Јовановић, 1957; Тодоровић, 1968; Трујић, 1976; Илић и Мијатовић, 2006; Вукашиновић, 2016).

\section{ЖИВОТОПИС СТЕВАНА ТОДОРОВИЋА - ВЕЧНОСТ СРПСКОГ ВЕЖБАЧКОГ И СПОРТСКОГ ПОКРЕТА}

Огроман и неуморан рад донели су Стеви Тодоровићу признања и материјалну сигурност за удобан живот у познијим годинама. За све што је урадио за живота Стева Тодоровић је почаствован и награђиван. У српско-турским ратовима (1876-1878) одликован је Таковским крстом четвртог и трећег реда, као ратни сликар и новински извештач. Само као уметник одликован је орденом Светог Саве трећег и другог реда, орденом Белог орла петог реда, Карађорђевом звездом четвртог реда, орденом кнеза Данила четвртог реда, орденом Италијанске круне другог реда... Биран је за почасног, а убрзо редовног члана Српске краљевске академије (1902), почасног члана Петровградске академије художества и италијанске Академије у Катанији. И за допринос у спорту одата су му бројна друштвена признања. За гимнастичаре и соколе, некада, а и данас, Стева је пионир, родоначелник, речју, великан телесног вежбања.

Стеван Тодоровић умро је 22. маја 1925. године, сахрањен је на Новом гробљу у Београду. Тада се на последњем испраћају од Чика Стеве окупило мноштво света, грађана, званичних представника бројних институција, уметника, глумаца, певача, и гимнастичара, сокола и спортиста. 


\title{
ЛИТЕРАТУРА
}

1. Вукашиновић, В. (2016). Гимнастичка и соколстиво у Србији gо 1941. іолине, великани

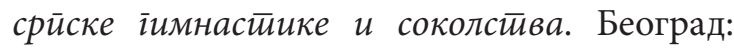
Универзитет у Београду, Факултет спорта и физичког васпитања.

2. Ђорђевић, В. (1927). Усйомене, кулйурне скиие из gруїе йоловине 19. века 1. Нови Сад: књижара „Славија“.

3. Илић, С., и Мијатовић, С. (2006). Истиорија бизичке кулииуре Кнежевине и Кралевине Србије, gруїо изgане, gео 3. Београд: Факултет физичке културе Универзитета у Београду.

4. Јефтимијадес, М. (1938). Чика Стева Тодоровић. Око соколово 2, 26-28.

5. Јовановић, Б. (1957). Поводом стогодишњице организованог физичког васпитања у Сpбији. Физичка куличура 7-8, 326-332.

6. Кусовац, Н., Врбашки, М., Грујић, В. и Краут, В. (2002). Сиевван Тоgоровић 1832-1925. Нови Сад: Народни музеј Београд, Галерија Матице српске.

7. Матић, М. (1975). Родоначелник покрета физичке културе у Србији, Стева Тодоровић (поводом 50-годишњице смрти). Физичка кулйура 2, 12-15.
8. Петровић, В. (1927). Тодоровић Стеван. У Нароgна енииклойеgија 4, ур. С. Станојевић. Нови Сад: Штампарија Будућност.

9. Петровић, В. Ј. (1983). Физичка култура до 1941. год. У Социјалистиичка рейублика Ср-

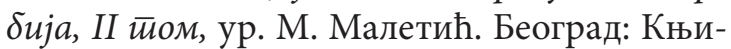
жевне новине.

10. Рашић, В. (1908). Споменица на прво српско соколско вече. Београд.

11. Симић М. 3. (1951). Ауйобиоі̄рафија Сӣеве Togopoвићa. Нови Сад: Матица српска.

12. Тодоровић, С. (1968). Стева Тодоровић (1832-1925) и Прво српско друштво за гимнастику и борење у Београду. Зборник за исйорију физичке кулйуре Србије, 2-3, 7-12.

13. Тодоровић, Стеван. (1899). Аутобиографија. Годишюак Срйске кратьевске акаgемије 12, 189-207.

14. Тодоровић, Стеван. (1912). Савез Свесловенског Соколства. У: Соколски іодинғак за 1911, ур. С. Обрадовић. Београд: Савез соколских друштава „Душан Силни“, 34-37.

15. Трујић, Никодије. (1976). Физичка куличура у школама Србије у 19. веку. Београд: Комисија за историју, архив и музеј физичке културе Србије.

\section{LEBEN UND WERK DES TURNERS, KÜNSTLERS, AUFKLÄRERS UND BEGRÜNDERS VON ORGANISIERTEM SPORT IN SERBIEN STEVAN TODOROVIĆ}

\begin{abstract}
Zusammenfassung
Im Jahr 2017 wurden 160 Jahre seit Beginn von organisierten körperlichen Übungen (1857) und 126 Jahre seit der Erscheinung der Sokolbewegung (1891) in Serbien gefeiert. Evoziert wurde der riesige Beitrag, den der Akademiker Steva Todorović, dr. Vladan Đorđevic und dr. Vojislav Rašić zu den Anfängen und der Entwicklung von Körperkultur im Fürstentum und Königtum Serbien geleistet haben. Es wurden 160 Jahre seit der Ankunft des Akademikers Stevan Todorović in der Hauptstadt Belgrad gekennzeichnet, in der er 1857 seine kulturelle und aufklärerische Arbeit begann. Im Rahmen der Malerschule, die er eröffnete, wurde eine „Genossenschaft für Gymnastik und Kampfsport" als erste organisierte Gesellschaft für körperliche Übungen gegründet. Diese Genossenschaft war ein Vorgänger für die Akzeptanz der Sokolbewegung, die Entwicklung des modernen Sports und die Affirmierung von Körperkultur in Serbien. Ziel dieser Arbeit ist es, den Beitrag des Akademikers Stevan Todorović zum insgesamten Progress von Kultur, Bildung und Körperkultur zu erleuchten. Durch eine historische Methode wurden authentische Dokumente aus den Jahren 1899, 1908, 1912, 1927, 1938 bearbeitet, die der breiteren und fachlichen Öffentlichkeit und Mitgliedern von Gymnastik- und Sokolvereinen nicht zugänglich waren.
\end{abstract}

Schlüsselwörter: STEVAN TODOROVIĆ / KÖRPERKULTUR / BILDUNG / KULTUR / KUNST / SERBIEN

Примљен: 05. 11. 2017. Прихваћен: 06. 12. 2017. 